\title{
Colorimetric evaluation of three adhesives used in the consolidation of contemporary matte paint after artificial ageing
}

\author{
Rosario Llamas* \\ Demian Ramos San Pedro \\ Instituto de Restauración del Patrimonio, Universidad Politécnica de Valencia, Departamento de Conservación \\ y Restauración de Bienes Culturales, Camino de Vera s/n, 46022, Valencia, España \\ *rllamas@crbc.upv.es
}

\begin{abstract}
Of all the problems associated to contemporary painting, the most complex is probably that which concerns powdering matte surfaces, both for their technical characteristics and optical properties and for the aesthetic significance associated to these types of finishes. These pictorial surfaces are technically complex due to the high risk of irreversible alterations associated to the appearance of the treated surface and the potential for streaking, tide lines, changes in colour, darkening, added gloss and changes in texture during the treatment process. For this study, a colorimetric analysis was performed to evaluate the behaviour of three adhesives commonly used in the consolidation of these types of painted surfaces, to determine the effect of ageing on the adhesives and quantify their stability as a function of adhesive type, concentration, and application method. Of all the adhesives, funori did not result in significant changes when aged using this method.
\end{abstract}

Avaliação colorimétrica de três adesivos utilizados na consolidação de tintas mate submetidas a envelhecimento artificial

\section{Resumo}

Dentro do heterogéneo grupo de problemas associados à pintura contemporânea, o caso de superfícies mate pulverulentas apresenta uma complexidade particular, tanto pelas suas características técnicas e propriedades ópticas, como pela significância estética deste tipo de acabamentos. Estas superfícies pictóricas são tecnicamente complexas, dado o elevado risco de alteração irreversível da aparência da superfície tratada e o possível aparecimento de riscos, linhas de maré, alterações da cor e/ou da textura, escurecimento e brilho durante o processo de intervenção. Neste estudo foi feita uma análise colorimétrica para avaliar o comportamento de três adesivos comummente usados na consolidação deste tipo de superfícies pictóricas, para determinar os efeitos do envelhecimento e a fim de quantificar a sua estabilidade em função da natureza, concentração e método de aplicação da substância adesiva. De todos os adesivos, apenas o funori não registou mudanças significativas após envelhecimento.

\section{Keywords}

Adhesives

Ageing

Colour change

Powdery paintings

Contemporary art

\section{Palavras-chave}

Adesivos

Envelhecimento

Alterações cromáticas

Pinturas pulverulentas

Arte Contemporânea 


\section{Research aims}

The aim of this study is to qualitatively and quantitatively describe the colorimetric stability of the three adhesives typically used in the consolidation of contemporary works of art featuring powdery matte surfaces. After undergoing accelerated ageing cycles using ultraviolet radiation and varying humidity and temperature, funori, Acril 33 and Gelvatol were evaluated for changes in colour as well as any effects upon the painted surfaces. The aim here was to compare changes in colour stability of these adhesives as a function of concentration and application method. The following application methods were used: consolidation using a paintbrush combined with controlled suction; consolidation using ultrasonic mister, and consolidation using ultrasonic mister and controlled suction. The effect of different methods of application will also be studied.

\section{Introduction}

The greater focus on concept-based art which began in the $1960 \mathrm{~s}$ is responsible for the special relationships that exist between an idea, the transmitter of message, and the materials chosen by the artist to convey the intended message in a particular work of art. The materials chosen by the artist hold a particular aesthetic and ideology, which are directly related to his/her philosophical concerns and artistic discourse. It is important to understand the conceptual load contained both in these materials and their aesthetic effect, and how these relate to the comprehension of the artistic message to understand the specific issues associated to a given work - a task which must be undertaken in the evaluation of the material and conceptual deterioration of a given work of art and its requirements in terms of the conservation and treatment [1].

In the case of monochromatic works, the pictorial space depends solely on the surface qualities of the work itself; as these works do not feature representations alluding to the personal or the particular. In these works, pure feeling is expressed by colour alone; no representational elements or anything associated to subjective meanings are used by the artist at all. The chromatic values of the work take on a dimension and a presence that lie somewhere between the spiritual and experiential [2-3]. This search for tangible representation through colour intensity led artists to investigate the artistic properties of raw pigment and the methods by which said pigment could be adhered to the support media without losing its vibrant powdery appearance. This enabled artists to produce matte and velvety surfaces in which the low binder-to-pigment ratio of the paint created subtle fields of ethereal colour. Yet these surfaces are continually at risk of loss of material due to the detachment of pigment particles with the slightest of movements.

Maintaining the coherent transmission of the concept behind this kind of monochromatic work depends upon a conservation process that does not alter the powdery surface of the painting. There are a number of options available to the conservator. The works can be displayed within a glass case, which ensures that any loose particles will be protected from the effects of vibration from both the building itself and the environment. Another option involves the consolidation of the pigment layer. The first option is ethically undesirable given that, for this type of work, the space in which the work is displayed is just as important as the work itself; many artists who make use of this artistic discourse are quite concerned with the displaying of their works, seeing the monochromatic painting as part of an installation in which the gallery and the rest of the his/her works stimulate the spectator in some way [2]. A display case would interfere with the concept of the work as an ethereal object within the gallery space. Yet the second option may endanger the technical properties of the work as it may easily and irreversibly alter the pictorial surface, and its monochromatic properties in turn [4].

Feller and Kunz [5], who pioneered the study of powdery surfaces, investigated the physical properties of porous matte paint in order to establish the physical parameters that would help identify the best method for their consolidation. Their studies mainly showed that the darkening of these surfaces was primarily due to the action of the adhesive on the surface, which eliminated the air-pigment interface. They conducted a battery of tests on paints with varying pigment concentrations using polymers with differing refractive indices, showing that the darkening effects were similar, regardless of the polymer used. Colour saturation occurred when the addition of the adhesive to a porous surface reduced the volume of void spaces, changing the pigment volume concentration $(\%$ PVC), which in turn decreases the solid-to-air interfaces which work to disperse the light. Colour perception depends on the PVC of a dry film; it can therefore be described as the result of a physiological effect arising from the interaction of light within a system with the system components (pigment, binder and interstitial air). This interaction is determined by the selective absorption and reflection of different wavelengths that make up white light. Reflection of light from a smooth surface produces specular reflection, which is perceived as glossy or shiny. If the surface has imperfections or defects, the light rays hit the interstices formed by said imperfections and are reflected in different directions and angles, giving the surface a matte appearance due to the diffuse reflection of the light rays [5-6].

The most common problem seen in this type of treatment is poor adhesive penetration. This occurs when the adhesive is too viscous to penetrate the small voids between pigment particles, or when the solvent evaporates before the solution has an opportunity to penetrate these spaces.

Consolidation in an atmosphere that is saturated with the solvent used to dissolve the adhesive is a technique that was developed to prevent the darkening of the surface 
and the appearance of tide lines [7]. Used on laboratory samples of wooden supports and ethnographic objects, this treatment showed good results using both fast and slow-evaporating solvents.

Michalski [8-9] focused on resin particle size, using an ultrasonic mister in the consolidation of powdery paint on ethnographic artefacts, both on samples without supports and actual paintings on wooden supports.

Nevertheless, research on the treatment of powdery surfaces created using contemporary paints [10] has shown that these treatments may cause colour saturation formed by the collapse and compaction of pigment particles during the adhesive curing phase, and not due to the formation of a solid film in the interstitial spaces between the particles. This process may also produce tide lines caused by an inadequate regulation of the velocity at which the mist is applied.

In addition to application methods, researchers have also studied the resins employed in the consolidation of powdery paint. Of these, the most noteworthy was the study conducted in the Australian Museum [11], a comprehensive and detailed investigation into the various types of resins, in both liquid and dissolved form, used in the treatment of ethnographic objects.

In recent years, numerous studies have dealt with the consolidation of contemporary matte paint, both on surfaces with good binder properties and those with powdery paint [12].

The current study is framed within another, larger work [13-14] on the consolidation of powdery surfaces of contemporary art works on canvas and the specific requirements and issues these works pose for the conservator. Initial results focused on the study of colour changes produced during the consolidation process, using three different water-based adhesives and several application methods. This experiment yielded interesting conclusions concerning consolidation treatments and provided valuable guidelines for the conservator.

The second part of this study is centred on the characterisation of colour changes arising from these same experimental models, after undergoing various cycles of accelerated aging.

\section{Experimental design}

\section{Materials and methods}

\section{Artist's materials}

Special attention was paid to contemporary artistic production to prepare samples whose characteristics closely matched those of contemporary artworks on canvas; samples were produced after interviewing contemporary artists, with the materials indicated by them [1]. Commercial canvases (Lienzos Levante) were selected as supports $(46 \mathrm{~cm} \times 38 \mathrm{~cm}$.). These contained cotton $(60 \%)$, polyester $(26 \%)$ and viscose $(14 \%)$ with a thread count of $12 \times 12$ threads per square centimetre. They were further prepared using animal glue sizing and alkyd primer for oil paint.

The paint film was created by mixing $7 \%$ No. 170 acrylic cobalt blue paint (Liquitex), $93 \%$ No. 93 ultramarine blue pigment (Microgiraltin: Agroquímica del Vallès) and deionised water

\section{Consolidation models}

Three adhesives typically used in the restoration of contemporary paintings were selected, bearing in mind their aqueous properties to ensure a suitable operation of the mister: Acril 33 (acrylic resin in aqueous dispersion), funori (polysaccharide) and Gelvatol (polyvinyl alcohol). The adhesives were dissolved in deionised water at different concentrations (by weight), according to type (Table 1). Vinyl and acrylic resins were prepared at low proportions to prevent the formation of gloss on the painted surface and to ensure correct operation of the mister, which may not work at high concentrations of adhesive. funori concentrations were higher since, unlike the other adhesives, this product does not hamper the work of the mister or affect the colour of the painted surface [15]. The various concentrations of funori were obtained by using a base solution: 1 gram of algae was soaked in $120 \mathrm{ml}$ of deionised water for 24 hours. The solution was then stirred at $1200 \mathrm{rpm}$ and a temperature of $40^{\circ} \mathrm{C}$ for 60 minutes, and then filtered. A drop of Biotin $\mathrm{N}$ biocide (Tributyltin naphthenate and quaternary ammonium salts) was then added to the solution.

Table 1

Concentration (by weight) of adhesives versus application method

\begin{tabular}{|c|c|c|c|c|c|c|c|c|c|c|c|c|}
\hline \multirow[b]{3}{*}{ Gelvatol } & \multicolumn{12}{|c|}{ Concentration (\%) } \\
\hline & \multicolumn{4}{|c|}{ Ultrasonic mister } & \multicolumn{4}{|c|}{ Ultrasonic mister + low pressure } & \multicolumn{4}{|c|}{ Paintbrush + low pressure } \\
\hline & 0.5 & 1.5 & 2.5 & 5 & 0.5 & 1.5 & 2.5 & 5 & 0.5 & 1.5 & 2.5 & 5 \\
\hline Acril33 & 0.5 & 1.5 & 2.5 & 5 & 0.5 & 1.5 & 2.5 & 5 & 0.5 & 1.5 & 2.5 & 5 \\
\hline Funori & 0.2 & 2 & 4 & 6 & 0.2 & 2 & 4 & 6 & 0.2 & 2 & 4 & 6 \\
\hline
\end{tabular}


The four different concentrations of the adhesives were applied to the facsimiles using three different application methods: ultrasonic misting (Becker Preservotec AGS 2000, at a particle size of $5 \mu \mathrm{m}$ ), low-pressure ultrasonic misting (micro-table model CTS NSD 11; suction was set at $4999.57 \mathrm{~Pa}$ ) and application using a paintbrush on Japanese paper at low pressure. The atmospheric parameters during the application processes were measured with a TESTO 608-H1 thermo-hygrometer, which registered a relative humidity of $65-70 \%$ and a temperature of $28-30^{\circ} \mathrm{C}$.

The application procedure involving the mister was standardised using the following procedure: before application, the mister was placed at the centre of a template at a distance of $10 \mathrm{~cm}$ from the surface to be treated. The surface was sprayed for 60 seconds and left to dry during another 60 seconds. In cases where the suction table was used, the micro-perforated plate was placed under the canvas [13-14].

For the artificial accelerated ageing tests, three samples of equal size $(5 \mathrm{~cm} \times 2.5 \mathrm{~cm})$ were extracted from each of the samples treated with adhesives. Blank commercial canvases and painted untreated samples were also extracted for artificial accelerated ageing tests.

\section{Accelerated ageing treatments}

Artificially accelerated photoageing was performed by way of ultraviolet radiation; the samples were exposed to ultraviolet light for a total of 400 hours in a QUV-Basic weathering chamber, at a constant temperature of $45^{\circ} \mathrm{C}$. This unit contains fluorescent UV lamps (QUVB-313EL), maximum emission at $295 \mathrm{~nm}$.

For the artificially accelerated ageing process involving varying humidity and temperature, i.e. thermal ageing, the samples were exposed to 270 hours of treatment in an environmental chamber (Dycometal DI-100), equivalent to four cold-dry cycles $\left(6^{\circ} \mathrm{C}, 30 \% \mathrm{HR}\right)$ and four warmhumid cycles $\left(40{ }^{\circ} \mathrm{C}, 80 \% \mathrm{HR}\right)$.

\section{Instrumentation}

\section{Microscope}

Specimens were studied using a Leica DMR optical microscope with an incident/transmitted light system and polarization system in all cases.

\section{Colorimetric analysis}

The measurements were taken with a Minolta CM2600d spectrophotometer using CIE standard illuminant D65 (daylight colour temperature $6500 \mathrm{~K}$ ) and a $10^{\circ}$ standard observer. Colorimetric measurements were obtained through repeated measurement of the selected areas of the test specimens in order to obtain the standard deviation value and by performing a minimum of three consecutive measurements, using the SCI mode (specular component included). The colour spaces used were CIELAB and CIELCH. The former enabled the calculation of the total chromatic difference between the two stimuli and the latter made information regarding lightness $\left(\mathrm{L}^{*}\right)$, saturation $\left(\mathrm{C}^{*}\right)$ and hue $\left(\mathrm{h}^{*}\right)$ more easily attainable. Both SCI (Specular Component Included) and SCE (Specular Component Excluded) values were measured in order to obtain the gloss difference.

\section{Results and discussion}

It was observed that the simultaneous use of misting and suction produces a more localised application of the adhesive, an effect which may be desirable for application to specific areas of an art work. Furthermore, when an application is combined with controlled suction, adhesive penetration was found to improve, as did the drying time [12-13].

\section{Thermal ageing}

Table 2 shows the difference in colour and lightness for the samples that underwent humidity and temperature ageing. Our results were based on data provided by Melgosa, who established a suprathreshold colour difference of 1.75 CIELAB units [16]. The results obtained do not exceed this suprathreshold value in any of the samples, regardless of adhesive or application method.

Analysis of the differences in lightness values $\left(\Delta \mathrm{L}^{*}\right)$ of all samples revealed that these were very low and negligible for all adhesives, save for those applied with a paintbrush. In these cases, the surfaces showed some darkening, which was imperceptible to the human eye, as in the values obtained for hue $\left(\mathrm{h}^{*}\right)$.

Breaking down the obtained results, it was shown that, at low concentrations, funori (Figure 1) is a stable adhesive as it did not underwent a great change in colour with respect to the control. The remaining samples generally obtained $\Delta \mathrm{E}^{*}$ values that were lower than 0.45 .

Acril 33 (Figure 2) seemed to remain stable at low concentrations with a $\Delta E^{*}$ value of 0.07-0.29 CIELAB units at these concentrations, regardless of the method of application, and resulted in the greatest colour difference for all three application methods at its highest concentration $(5 \%)$ both in terms of total colour values $\left(\Delta \mathrm{E}^{*}=0.32\right.$ with the mister, $\Delta \mathrm{E}^{*}=0.52$ using mister and suction, and $\Delta \mathrm{E}^{*}=0.47$ for the application using a paintbrush and suction) and lightness, causing the most darkening when applied using a paintbrush.

Gelvatol (Figure 3) produced a difference in colour that was generally like Acril 33, and similar at all concentrations. Note that the largest deviation can be seen for the $1.5 \%$ concentration applied with the brush $\left(\Delta \mathrm{E}^{*}=0.47\right)$.

The variation in gloss produced by the adhesives applied on colour films was found to be almost nil. The 


\section{Table 2}

Lightness $\left(\Delta \mathrm{L}^{*}\right)$, saturation $\left(\Delta \mathrm{C}^{*}\right)$ and hue $\left(\Delta \mathrm{h}^{*}\right)$ before (1) and after (2) thermal ageing for the consolidated samples and its colour $\left(\Delta \mathrm{E}^{*}\right)$ and gloss change $(\Delta \mathrm{G})(\mathrm{UM}$ : ultrasonic mister; LP: low pressure; B: paintbrush)

\begin{tabular}{|c|c|c|c|c|c|c|c|c|c|c|c|}
\hline Sample & $\mathrm{L}^{*}(1)$ & $\mathrm{L} *(2)$ & $\Delta \mathrm{L}^{*}$ & $C^{*}(1)$ & $C^{*}(2)$ & $\Delta \mathrm{C}^{*}$ & $\mathrm{~h}^{*}(1)$ & $\mathrm{h}^{*}(2)$ & $\Delta \mathrm{h}^{*}$ & $\Delta \mathrm{E}^{*}$ & $\Delta \mathrm{G}$ \\
\hline Gelvatol $0.5 \%$ - UM & 44.10 & 44.17 & 0.07 & 41.89 & 41.91 & 0.02 & 244.52 & 244.25 & -0.27 & 0.21 & 0.00 \\
\hline Gelvatol $1.5 \%$ - UM & 43.69 & 43.66 & -0.03 & 42.31 & 42.34 & 0.03 & 244.45 & 244.26 & -0.19 & 0.14 & -0.01 \\
\hline Gelvatol $2.5 \%$ - UM & 43.17 & 43.05 & -0.12 & 41.90 & 42.12 & 0.21 & 245.06 & 244.92 & -0.14 & 0.26 & 0.00 \\
\hline Gelvatol $5 \%$ - UM & 45.85 & 45.92 & 0.07 & 41.36 & 41.60 & 0.24 & 244.12 & 243.84 & -0.29 & 0.32 & 0.02 \\
\hline Gelvatol $0.5 \%$ - UM + LP & 44.27 & 44.19 & -0.08 & 42.25 & 42.20 & -0.05 & 244.04 & 243.86 & -0.18 & 0.16 & 0.00 \\
\hline Gelvatol $1.5 \%$ - UM + LP & 43.91 & 43.89 & -0.02 & 42.03 & 42.15 & 0.12 & 244.48 & 244.16 & -0.32 & 0.27 & 0.03 \\
\hline Gelvatol $2.5 \%$ - UM + LP & 43.85 & 43.78 & -0.08 & 42.29 & 42.44 & 0.14 & 244.33 & 244.08 & -0.25 & 0.25 & 0.03 \\
\hline Gelvatol $5 \%$ - UM + LP & 44.83 & 44.90 & 0.06 & 42.51 & 42.41 & -0.10 & 243.91 & 243.76 & -0.15 & 0.16 & 0.02 \\
\hline Gelvatol $0.5 \%$ - B + LP & 44.16 & 44.16 & 0.00 & 41.61 & 41.60 & -0.01 & 244.23 & 244.02 & -0.21 & 0.15 & 0.02 \\
\hline Gelvatol $1.5 \%$ - B + LP & 42.89 & 42.42 & -0.46 & 42.06 & 42.09 & 0.03 & 244.80 & 244.91 & 0.12 & 0.47 & -0.02 \\
\hline Gelvatol $2.5 \%$ - B + LP & 40.88 & 40.80 & -0.08 & 42.89 & 42.83 & -0.07 & 245.46 & 245.37 & -0.09 & 0.13 & 0.03 \\
\hline Gelvatol $5 \%$ - B + LP & 41.18 & 41.10 & -0.05 & 42.25 & 42.22 & -0.03 & 244.87 & 244.80 & -0.10 & 0.10 & 0.01 \\
\hline Funori $0.2 \%$ - UM & 40.20 & 40.40 & 0.20 & 44.33 & 44.14 & -0.19 & 246.24 & 246.10 & -0.14 & 0.30 & -0.03 \\
\hline Funori $2 \%$ - UM & 40.54 & 40.24 & -0.30 & 44.29 & 44.29 & 0.00 & 245.95 & 246.02 & 0.07 & 0.31 & 0.01 \\
\hline Funori $4 \%$ - UM & 41.90 & 41.75 & -0.15 & 44.22 & 44.16 & -0.05 & 245.04 & 244.94 & -0.10 & 0.18 & -0.02 \\
\hline Funori $6 \%$ - UM & 41.84 & 41.40 & -0.44 & 44.16 & 44.21 & 0.05 & 245.04 & 245.09 & 0.05 & 0.44 & -0.01 \\
\hline Funori $0.2 \%$ - UM + LP & 40.95 & 41.03 & 0.07 & 43.95 & 43.97 & 0.02 & 245.82 & 245.64 & -0.18 & 0.16 & 0.01 \\
\hline Funori $2 \%-U M+L P$ & 38.95 & 39.02 & 0.07 & 44.82 & 44.82 & 0.00 & 246.47 & 246.41 & -0.06 & 0.09 & 0.01 \\
\hline Funori $4 \%$ - UM + LP & 39.33 & 39.28 & -0.05 & 45.32 & 45.36 & 0.04 & 246.27 & 246.35 & 0.08 & 0.09 & 0.03 \\
\hline Funori $6 \%$ - UM + LP & 41.26 & 41.06 & -0.20 & 44.27 & 44.31 & 0.04 & 245.23 & 245.26 & 0.03 & 0.21 & 0.00 \\
\hline Funori $0.2 \%$ - B + LP & 42.44 & 42.55 & 0.11 & 43.03 & 42.99 & -0.04 & 244.74 & 244.67 & -0.07 & 0.12 & 0.02 \\
\hline Funori $2 \%-B+L P$ & 40.72 & 39.98 & -0.74 & 44.06 & 44.24 & 0.18 & 245.81 & 245.87 & 0.06 & 0.76 & -0.03 \\
\hline Funori $4 \%$ - B + LP & 40.94 & 41.07 & 0.13 & 43.92 & 43.93 & 0.01 & 245.42 & 245.30 & -0.12 & 0.16 & -0.01 \\
\hline Funori $6 \%$ - B + LP & 41.33 & 41.27 & -0.07 & 44.63 & 44.64 & 0.02 & 245.43 & 245.39 & -0.04 & 0.08 & -0.01 \\
\hline Acril $0.5 \%$ - UM & 40.77 & 40.73 & -0.04 & 45.81 & 45.76 & -0.05 & 244.38 & 244.33 & -0.04 & 0.07 & 0.04 \\
\hline Acril $1.5 \%$ - UM & 41.63 & 41.53 & -0.10 & 45.32 & 45.35 & 0.03 & 244.01 & 244.05 & 0.04 & 0.11 & 0.01 \\
\hline Acril $2.5 \%$ - UM & 42.04 & 41.98 & -0.06 & 45.58 & 45.51 & -0.07 & 243.39 & 243.40 & 0.00 & 0.09 & -0.02 \\
\hline Acril $5 \%$ - UM & 42.15 & 41.83 & -0.32 & 45.29 & 45.30 & 0.01 & 242.99 & 243.04 & 0.06 & 0.32 & -0.01 \\
\hline Acril $0.5 \%-\mathrm{UM}+\mathrm{LP}$ & 39.70 & 39.60 & -0.10 & 45.12 & 45.17 & 0.05 & 245.35 & 245.39 & 0.04 & 0.11 & 0.01 \\
\hline Acril $1.5 \%$ - UM + LP & 41.11 & 40.99 & -0.12 & 45.29 & 45.21 & -0.08 & 244.29 & 244.33 & 0.04 & 0.15 & -0.03 \\
\hline Acril $2.5 \%-\mathrm{UM}+\mathrm{LP}$ & 41.26 & 41.30 & 0.01 & 45.44 & 45.32 & -0.12 & 244.52 & 244.43 & -0.09 & 0.14 & 0.00 \\
\hline Acril $5 \%$ - UM + LP & 41.51 & 41.60 & 0.09 & 44.77 & 44.65 & -0.12 & 244.51 & 244.60 & 0.09 & 0.52 & -0.15 \\
\hline Acril $0.5 \%$ - B + LP & 40.62 & 40.87 & 0.25 & 44.19 & 44.14 & -0.05 & 245.09 & 244.92 & -0.18 & 0.29 & -0.01 \\
\hline Acril $1.5 \%-B+L P$ & 39.09 & 39.10 & -0.02 & 44.95 & 45.15 & 0.19 & 245.79 & 245.73 & -0.06 & 0.20 & 0.02 \\
\hline Acril $2.5 \%$ - B + LP & 38.19 & 38.08 & -0.11 & 44.86 & 44.77 & -0.09 & 246.29 & 246.17 & -0.11 & 0.17 & 0.00 \\
\hline Acril $5 \%-B+L P$ & 38.12 & 37.67 & -0.45 & 44.77 & 44.89 & 0.12 & 245.90 & 245.82 & -0.07 & 0.47 & -0.01 \\
\hline
\end{tabular}




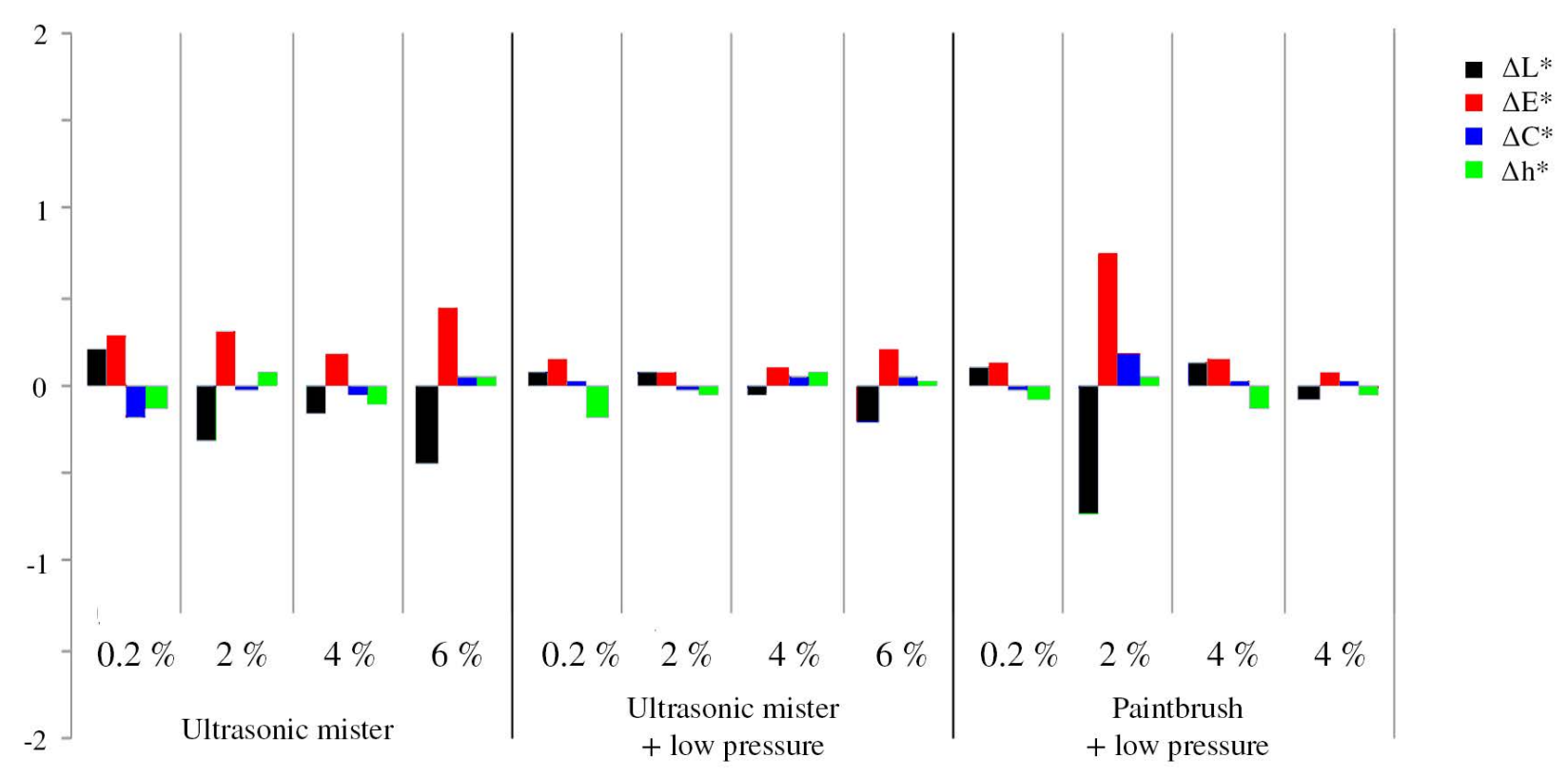

Figure 1. Change in lightness $\left(\Delta \mathrm{L}^{*}\right)$, colour $\left(\Delta \mathrm{E}^{*}\right)$, saturation $\left(\Delta \mathrm{C}^{*}\right)$ and hue $\left(\Delta \mathrm{h}^{*}\right)$ after thermal aging for the samples consolidated with funori.

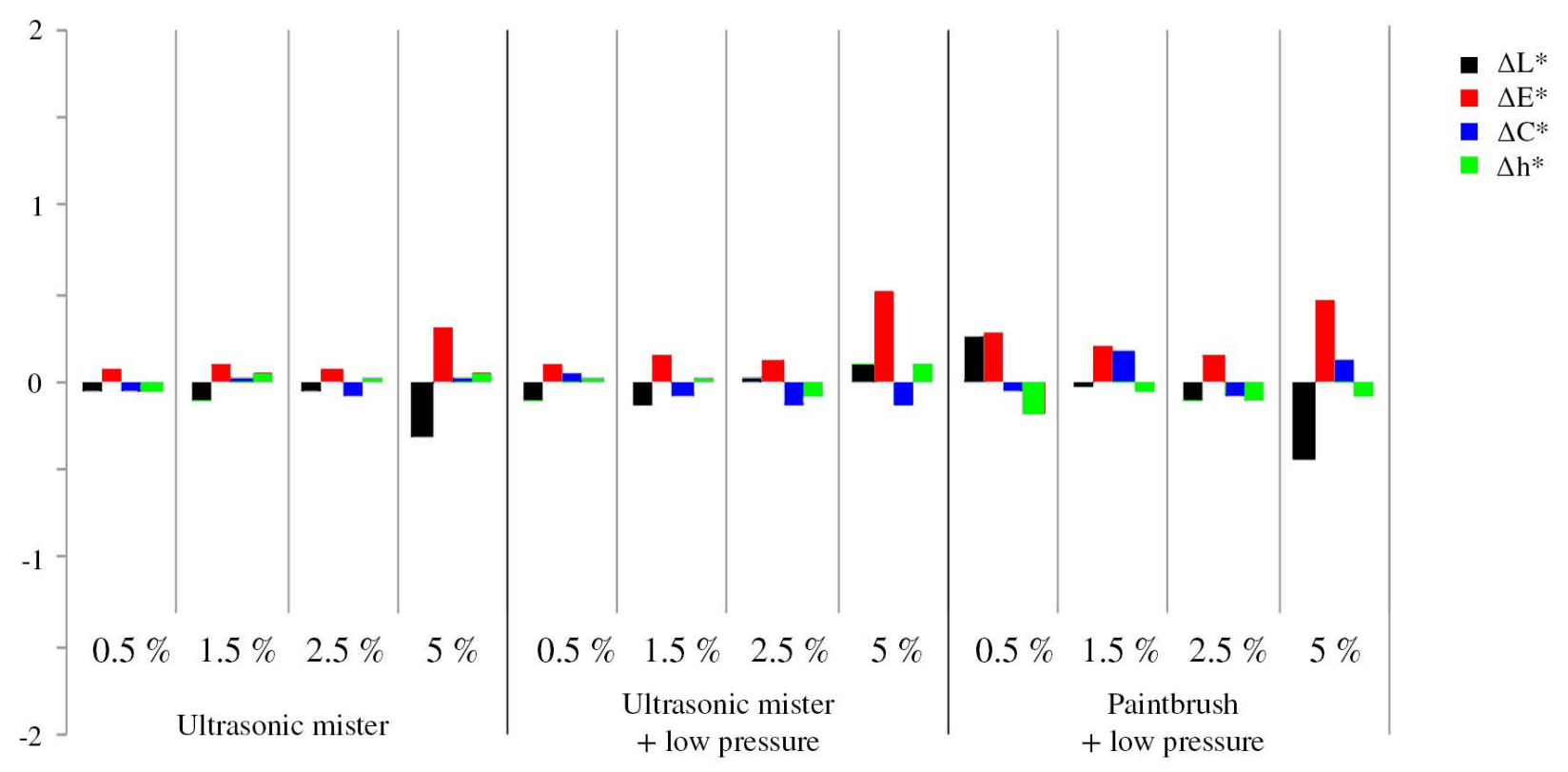

Figure 2. Change in lightness $\left(\Delta \mathrm{L}^{*}\right)$, colour $\left(\Delta \mathrm{E}^{*}\right)$, saturation $\left(\Delta \mathrm{C}^{*}\right)$ and hue $\left(\Delta \mathrm{h}^{*}\right)$ after thermal aging for the samples consolidated with Acril 33.

average gloss difference in the case of funori was 0 , while for Gelvatol and Acril 33 this average gloss difference was found to be 0.01 and -0.01 respectively. The average change in gloss as a function of application method is 0 for all methods.

\section{Photoageing}

When the samples were artificially aged using ultraviolet radiation, a change in the overall parameters of all samples was observed, except for the blank commercial canvas sample. Measurements taken from unconsolidated samples showed that this significant difference was mostly attributable to the ageing of the painted surface itself, and not the consolidants. Given that the aim of the present study is to analyse the behaviour of the adhesives and not of the acrylic paints, the average of chromatic variations was calculated for unconsolidated samples, both artificially aged and not $\left(\Delta \mathrm{E}^{*}=6.33 ; \Delta \mathrm{L}^{*}=3.75 ; \Delta \mathrm{C}^{*}=-3.04 ; \Delta \mathrm{h}^{*}=4.98\right)$. This average was compared to the consolidated samples in order to obtain the variation caused by adhesive. The 


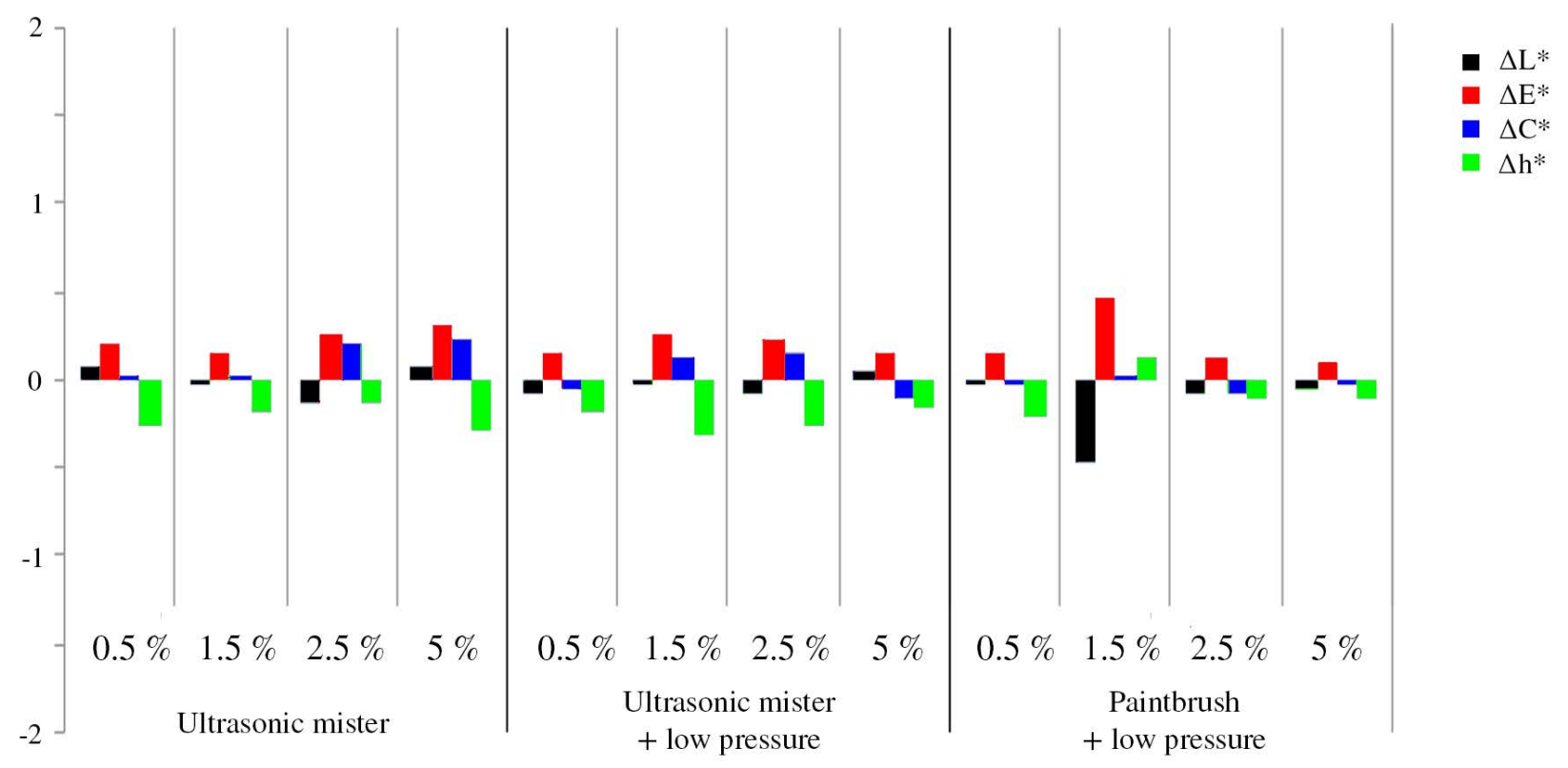

Figure 3. Change in lightness $\left(\Delta \mathrm{L}^{*}\right)$, colour $\left(\Delta \mathrm{E}^{*}\right)$, saturation $\left(\Delta \mathrm{C}^{*}\right)$ and hue $\left(\Delta \mathrm{h}^{*}\right)$ after thermal aging for the samples consolidated with Gelvatol.

values of colour and gloss variation of the consolidants without the changes to the painted film are provided in Table 3.

Funori (Figure 4) fared the best under the ultraviolet radiation treatment, yielding $\Delta \mathrm{E}^{*}$ values that were lower than one, except for those samples which received consolidation treatment using higher concentrations of adhesive applied with the paintbrush (4\% and $6 \%$ ) and ultrasonic mister under low pressure $(4 \%)$. The highest change was found in the sample where the adhesive was applied with paintbrush at the highest concentration, $6 \%$ $\left(\Delta \mathrm{E}^{*}=1.18\right)$.

Gelvatol (Figure 5) was also shown to be sensitive to ultraviolet radiation. Some of the samples were observed to have $\Delta \mathrm{E}^{*}$ values greater than 1 CIELAB unit. Nevertheless, the changes observed with Gelvatol were not as acute as with Acril 33. Similarly to the funori samples, the samples treated with higher Gelvatol concentrations showed some darkening (negative $\Delta \mathrm{L} *$ values).

Acril 33 (Figure 6) was found to be the most sensitive to ultraviolet radiation, resulting in the

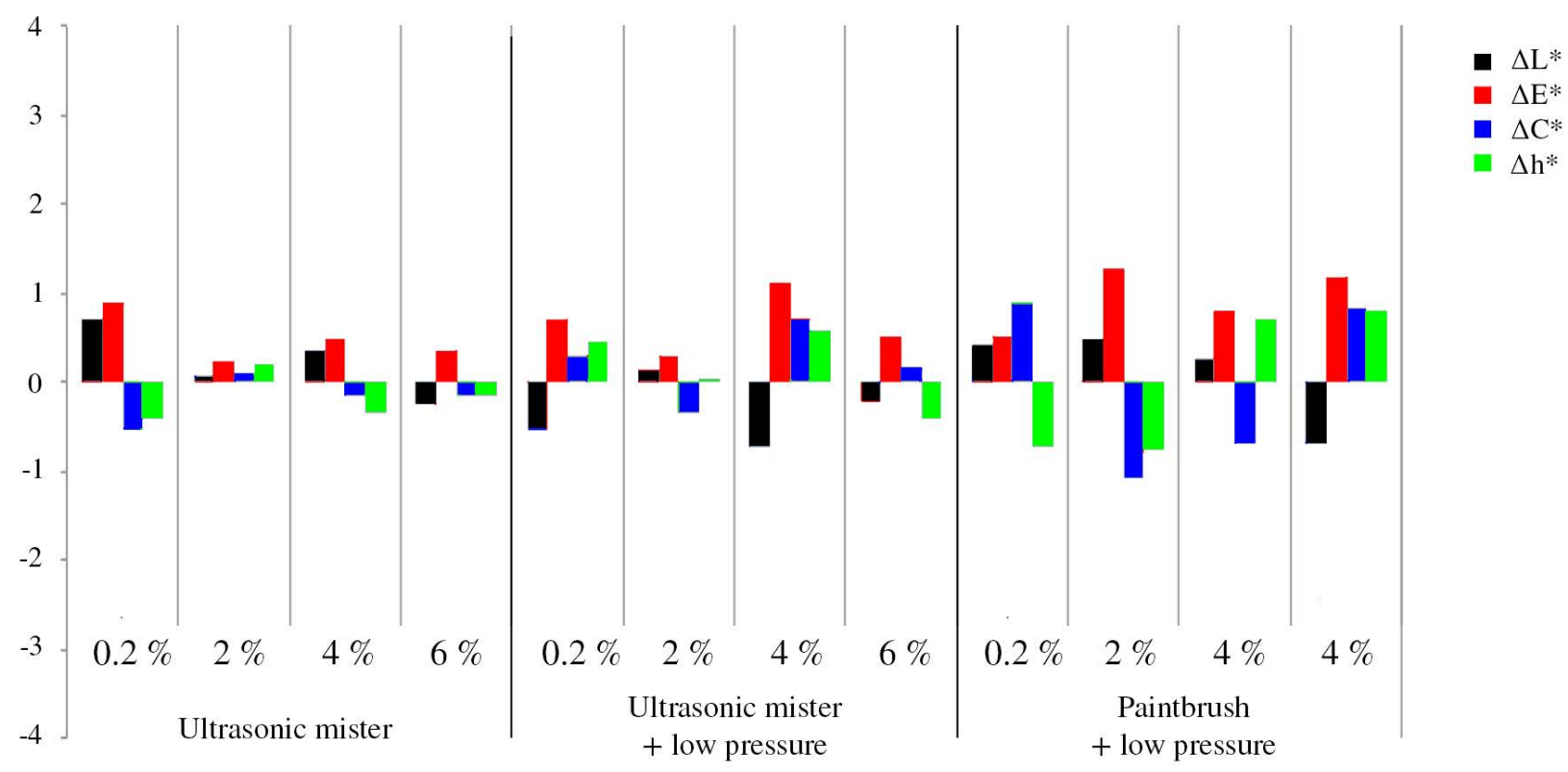

Figure 4. Change in lightness $\left(\Delta \mathrm{L}^{*}\right)$, colour $\left(\Delta \mathrm{E}^{*}\right)$, saturation $\left(\Delta \mathrm{C}^{*}\right)$ and hue $\left(\Delta \mathrm{h}^{*}\right)$ after photoageing for the samples consolidated with funori. 


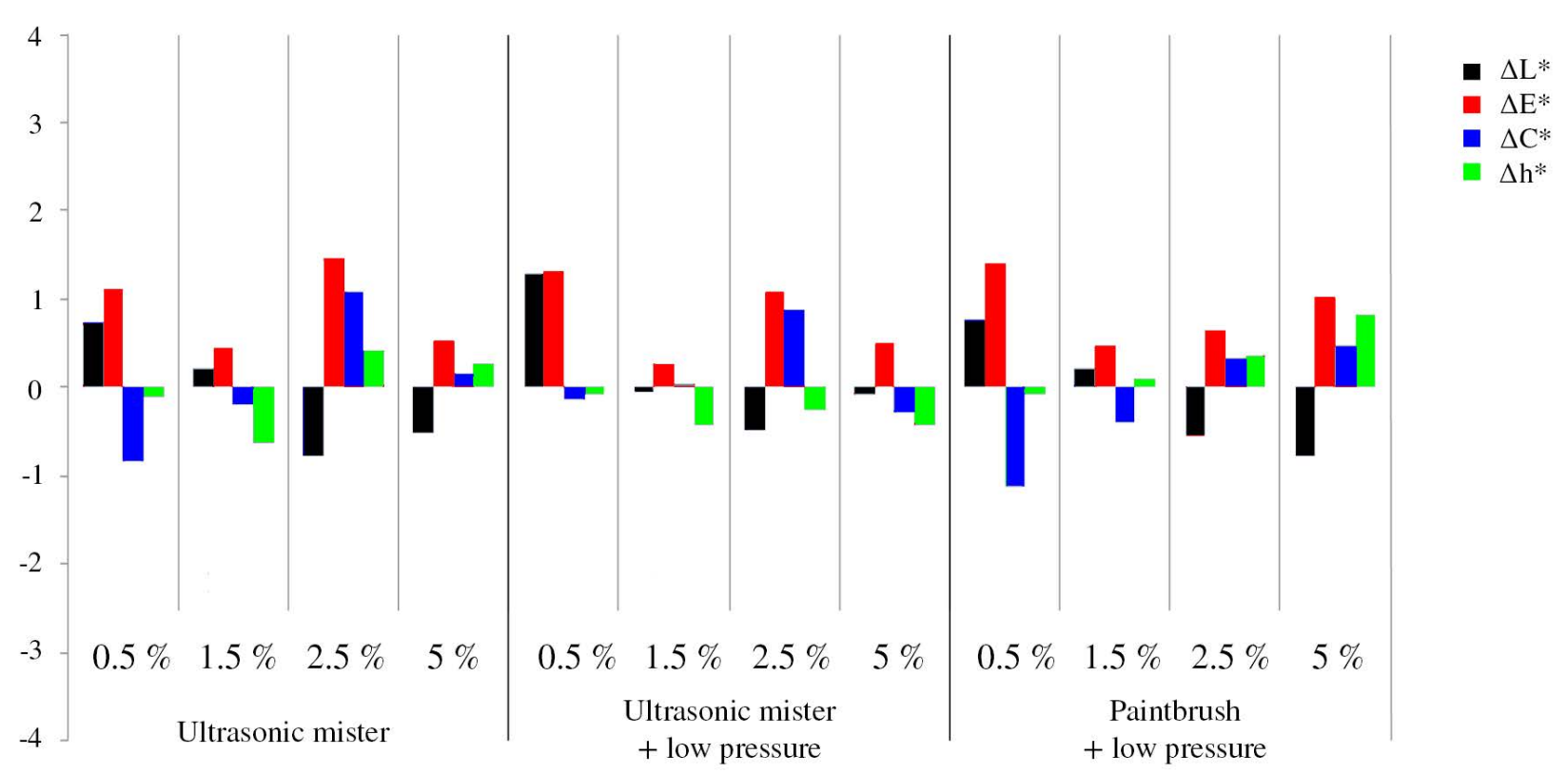

Figure 5. Change in lightness $\left(\Delta \mathrm{L}^{*}\right)$, colour $\left(\Delta \mathrm{E}^{*}\right)$, saturation $\left(\Delta \mathrm{C}^{*}\right)$ and hue $\left(\Delta \mathrm{h}^{*}\right)$ after photoageing for the samples consolidated with Gelvatol.

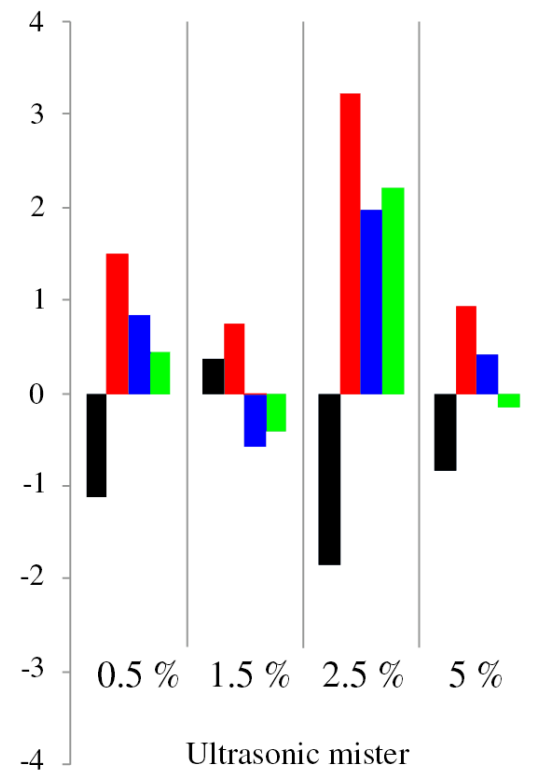

$-4$

Ultrasonic mister
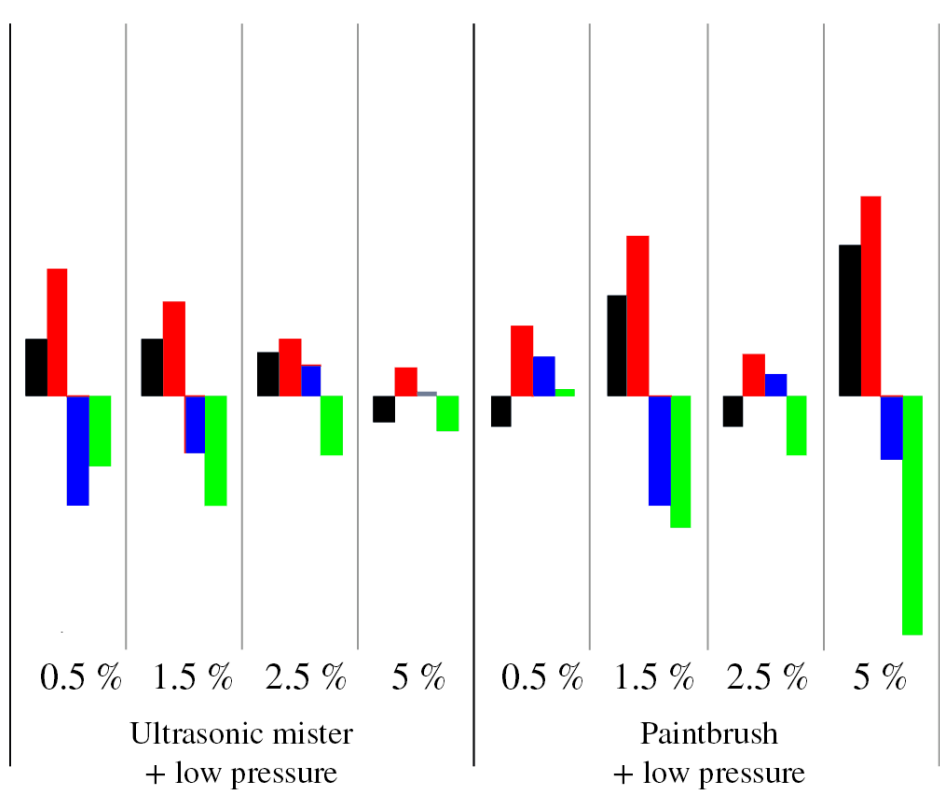

- $\Delta \mathrm{L}^{*}$

- $\Delta \mathrm{E}^{*}$

- $\Delta \mathrm{C}^{*}$

$\Delta \mathrm{h} *$

Figure 6. Change in lightness $\left(\Delta \mathrm{L}^{*}\right)$, colour $\left(\Delta \mathrm{E}^{*}\right)$, saturation $\left(\Delta \mathrm{C}^{*}\right)$ and hue $\left(\Delta \mathrm{h}^{*}\right)$ after photoageing for the samples consolidated with Acril 33.

greatest differences. Half of the $\Delta \mathrm{E}^{*}$ values were greater than 1 , with the highest found at a concentration of $2.5 \%$ using the mister, which resulted in a $\Delta \mathrm{E}^{*}$ value of 3.23 CIELAB units. The samples treated with concentrations of $2.5 \%$ and $5 \%$ using a paintbrush produced a $\Delta \mathrm{E}^{*}$ value of 1.70 and $2.14 \mathrm{CIELAB}$ units respectively.

The influence of the gloss produced by the application of adhesives on the pigment layer after artificial aging was found to be nil. The average difference in the case of funori is -0.02 , the value for Gelvatol was found to be -0.03 and for Acril 33 the average difference in gloss was -0.01. In terms of gloss difference as a function of application method, a value of -0.02 was found for all methods.

\section{Conclusions}

Thermal ageing hardly produces chromatic variations on any of the three cases. Changes are most noticeable with photoageing. 


\section{Table 3}

Corrected values of lightness $\left(\Delta \mathrm{L}^{*}\right)$, saturation $\left(\Delta \mathrm{C}^{*}\right)$ and hue $\left(\Delta \mathrm{h}^{*}\right)$ before (1) and after (2) thermal ageing for the consolidated samples and its colour $\left(\Delta \mathrm{E}^{*}\right)$ and gloss change $(\Delta \mathrm{G})$ (UM: ultrasonic mister; LP: low pressure; B: paintbrush)

\begin{tabular}{|c|c|c|c|c|c|c|c|c|c|c|c|}
\hline Sample & $\mathrm{L} *(1)$ & $L^{*}(2)$ & $\Delta \mathrm{L}^{*}$ & $C^{*}(1)$ & $C^{*}(2)$ & $\Delta \mathrm{C}^{*}$ & $\mathrm{~h}^{*}(1)$ & $\mathrm{h} *(2)$ & $\Delta \mathrm{h}^{*}$ & $\Delta \mathrm{E}^{*}$ & $\Delta \mathrm{G}$ \\
\hline Gelvatol $0.5 \%$ - UM & 43.40 & 44.14 & 0.73 & 39.13 & 38.29 & -0.85 & 242.69 & 242.59 & -0.10 & 1.12 & -0.03 \\
\hline Gelvatol $1.5 \%$ - UM & 41.85 & 42.05 & 0.21 & 38.93 & 38.72 & -0.20 & 243.51 & 242.87 & -0.64 & 0.44 & 0.02 \\
\hline Gelvatol $2.5 \%$ - UM & 41.35 & 40.57 & -0.78 & 38.18 & 39.26 & 1.08 & 243.90 & 244.32 & 0.42 & 1.45 & -0.10 \\
\hline Gelvatol $5 \%$ - UM & 44.64 & 44.13 & -0.51 & 39.91 & 40.07 & 0.16 & 242.22 & 242.48 & 0.26 & 0.54 & 0.02 \\
\hline Gelvatol $0.5 \%$ - UM + LP & 44.56 & 45.85 & 1.29 & 38.89 & 38.77 & -0.13 & 241.60 & 241.51 & -0.09 & 1.30 & -0.04 \\
\hline Gelvatol $1.5 \%$ - UM + LP & 42.01 & 41.96 & -0.05 & 39.23 & 39.24 & 0.01 & 243.27 & 242.85 & -0.42 & 0.26 & 0.01 \\
\hline Gelvatol $2.5 \%$ - UM + LP & 40.94 & 40.45 & -0.49 & 38.88 & 39.77 & 0.89 & 243.80 & 243.56 & -0.24 & 1.08 & -0.10 \\
\hline Gelvatol $5 \%$ - UM + LP & 44.23 & 44.17 & -0.07 & 40.13 & 39.84 & -0.28 & 242.05 & 241.62 & -0.43 & 0.51 & -0.02 \\
\hline Gelvatol $0.5 \%$ - B + LP & 45.69 & 46.44 & 0.75 & 39.29 & 38.17 & -1.11 & 241.13 & 241.06 & -0.07 & 1.41 & -0.10 \\
\hline Gelvatol $1.5 \%$ - B + LP & 44.24 & 44.45 & 0.21 & 38.87 & 38.48 & -0.39 & 242.02 & 242.10 & 0.08 & 0.47 & -0.04 \\
\hline Gelvatol $2.5 \%$ - B + LP & 43.72 & 43.18 & -0.55 & 39.50 & 39.82 & 0.32 & 242.32 & 242.68 & 0.36 & 0.66 & -0.01 \\
\hline Gelvatol $5 \%$ - B + LP & 44.34 & 43.55 & -0.78 & 39.20 & 39.67 & 0.48 & 241.65 & 242.48 & 0.83 & 1.03 & 0.01 \\
\hline Funori $0.2 \%$ - UM & 41.66 & 42.37 & 0.70 & 41.20 & 40.66 & -0.54 & 243.25 & 242.83 & -0.41 & 0.89 & 0.03 \\
\hline Funori $2 \%$ - UM & 42.03 & 42.11 & 0.08 & 41.14 & 41.22 & 0.09 & 243.11 & 243.32 & 0.21 & 0.23 & 0.01 \\
\hline Funori $4 \%$ - UM & 42.18 & 42.52 & 0.35 & 41.31 & 41.17 & -0.15 & 242.82 & 242.48 & -0.34 & 0.47 & -0.03 \\
\hline Funori $6 \%$ - UM & 42.86 & 42.60 & -0.26 & 41.35 & 41.19 & -0.16 & 242.16 & 242.00 & -0.16 & 0.37 & -0.02 \\
\hline Funori $0.2 \%$ - UM + LP & 42.40 & 41.87 & -0.53 & 40.92 & 41.21 & 0.29 & 242.80 & 243.25 & 0.45 & 0.70 & 0.00 \\
\hline Funori $2 \%$ - UM + LP & 42.44 & 42.56 & 0.12 & 40.88 & 40.54 & -0.34 & 242.88 & 242.90 & 0.02 & 0.29 & -0.02 \\
\hline Funori $4 \%$ - UM + LP & 41.84 & 41.12 & -0.72 & 41.48 & 42.18 & 0.70 & 243.05 & 243.63 & 0.59 & 1.13 & -0.02 \\
\hline Funori $6 \%$ - UM + LP & 41.77 & 41.55 & -0.22 & 41.85 & 42.00 & 0.16 & 242.92 & 242.52 & -0.40 & 0.52 & -0.05 \\
\hline Funori $0.2 \%$ - B + LP & 43.13 & 43.55 & 0.42 & 40.67 & 41.56 & 0.89 & 242.08 & 241.36 & -0.72 & 0.51 & -0.05 \\
\hline Funori $2 \%$ - B + LP & 43.18 & 43.67 & 0.49 & 40.98 & 39.91 & -1.06 & 242.42 & 241.66 & -0.76 & 1.27 & -0.04 \\
\hline Funori $4 \%$ - B + LP & 42.84 & 43.09 & 0.26 & 41.61 & 40.93 & -0.68 & 242.10 & 242.81 & 0.72 & 0.79 & -0.03 \\
\hline Funori $6 \%$ - B + LP & 42.76 & 42.08 & -0.68 & 41.80 & 42.63 & 0.83 & 242.20 & 242.99 & 0.79 & 1.18 & 0.00 \\
\hline Acril $0.5 \%$ - UM & 41.68 & 40.57 & -1.12 & 42.93 & 43.77 & 0.84 & 241.77 & 242.22 & 0.45 & 1.50 & -0.05 \\
\hline Acril $1.5 \%$ - UM & 42.89 & 43.25 & 0.36 & 42.63 & 42.05 & -0.57 & 241.00 & 240.59 & -0.41 & 0.74 & -0.06 \\
\hline Acril $2.5 \%$ - UM & 43.23 & 41.38 & -1.85 & 42.46 & 44.44 & 1.98 & 240.68 & 242.89 & 2.21 & 3.23 & 0.02 \\
\hline Acril $5 \%$ - UM & 41.88 & 41.06 & -0.83 & 41.17 & 41.58 & 0.41 & 241.22 & 241.08 & -0.14 & 0.93 & -0.02 \\
\hline Acril $0.5 \%$ - UM + LP & 41.33 & 41.94 & 0.61 & 42.44 & 41.25 & -1.18 & 241.89 & 241.12 & -0.77 & 1.37 & -0.01 \\
\hline Acril $1.5 \%$ - UM + LP & 40.81 & 41.41 & 0.60 & 42.29 & 41.67 & -0.62 & 242.38 & 241.18 & -1.19 & 1.01 & 0.00 \\
\hline Acril $2.5 \%$ - UM + LP & 40.22 & 40.69 & 0.47 & 42.32 & 42.65 & 0.33 & 242.73 & 242.08 & -0.65 & 0.61 & 0.00 \\
\hline Acril $5 \%-\mathrm{UM}+\mathrm{LP}$ & 43.52 & 43.24 & -0.29 & 42.41 & 42.44 & 0.03 & 241.36 & 240.97 & -0.38 & 0.29 & 0.03 \\
\hline Acril $0.5 \%$ - B + LP & 42.12 & 41.78 & -0.34 & 41.04 & 41.46 & 0.42 & 242.50 & 242.56 & 0.06 & 0.75 & 0.02 \\
\hline Acril $1.5 \%$ - B + LP & 41.73 & 42.81 & 1.08 & 41.82 & 40.64 & -1.18 & 242.56 & 241.13 & -1.43 & 1.70 & -0.03 \\
\hline Acril $2.5 \%-B+L P$ & 41.50 & 41.17 & -0.34 & 42.18 & 42.41 & 0.23 & 242.63 & 241.99 & -0.64 & 0.45 & -0.02 \\
\hline Acril $5 \%$ - B + LP & 39.62 & 41.23 & 1.62 & 41.01 & 40.33 & -0.69 & 243.84 & 241.26 & -2.58 & 2.14 & 0.02 \\
\hline
\end{tabular}


Upon evaluation of the differences observed in colour after consolidant application and ageing tests, funori applied with the mister (with and without suction) yielded the best results for the type of paint used in this study. As an adhesive, funori was shown to behave favourably even at high concentrations, allowing for surface consolidation using the mister regardless of whether it is employed at a low pressure or not, thus providing various treatment options based on the specific characteristics of the work. The synthetic adhesives used in this study showed greater sensitivity to ultraviolet light in the ageing treatment used.

As far as the addition of gloss is concerned, after the consolidation treatment and accelerated artificial aging processes were applied, no changes in gloss were observed on the painted surfaces for any adhesives at the concentrations employed or application methods used in this study.

Using low concentrations of film-forming substances aids penetration through the poorly cohesive pigment particles; consequently the picture surface is not altered and no brightness conditions change.

Although it was found that added gloss resulting from consolidation is not a problem with the parameters used in this study, there still may be issues associated to the saturation of the powdery pigment surface due to compaction of pigment particles.

Funori and Gelvatol have a better resistance to photoageing and remain within the ranges that advise their use. Acril 33 would not be as suitable for this particular problem because in some cases it induces changes perceptible to the human eye.

\section{List of suppliers}

Cotton canvases: Manufactured by Lienzos Levante Artículos para Bellas Artes, Carretera Cocentaina km. 144, Muro Alcoy, Alicante, Spain (Tel.: 965530251 / e-mail: lienzos_1@ infonegocio.com); and purchased by Viguer S.L. - Material para Bellas Artes, Camino de Vera, 46071 Valencia, Spain (Tel.: 00 34963919054 / e-mail: info@ viguer.com).

Pigment Blue Microgiraltin num. 93 and Cobalt Blue "Liquitex": purchased by Viguer S.L. - Material para Bellas Artes, Camino de Vera, 46071 Valencia, Spain (Tel.: 0034963 919054 / e-mail: info@viguer.com).

Acril 33, Gelvatol, funori and Biotin: Purchased by CTS España Productos y Equipos para la Restauración S.L., C/ Monturiol, 9, Polígono Industrial San Marcos, Getafe, Madrid, Spain (Tel. +34916011640 / e-mail: cts.espana@ctseurope. com).

\section{Acknowledgements}

We gratefully acknowledge the assistance of Dr. Dolores Yusá, Dr. Marisa Martínez and Dr. Laura Osete of the Instituto de Restauración del Patrimonio of the Universidad Politécnica de Valencia.

This study forms part of the HAR2013-41010-P project, funded by the Office of the Secretary-General for Research, Development and Innovation, part of Spain's Ministry for Economy and Competitiveness.

\section{References}

1 Llamas, R., Conservar y Restaurar el Arte Contemporáneo. Un Campo Abierto a la Investigación, Universidad Politécnica de Valencia, Valencia (2009).

2 Van de Vall, R., 'Painful decisions: philosophical considerations on a decision-making model', in Modern Art: Who Cares?, Foundation for the Conservation of Modern Art/ Netherlands Institute for Cultural Heritage, Amsterdam (1999) 196-200.

3 Van de Wetering, E., 'Conservation-restoration ethics and the problem of modern art', in Modern Art: Who Cares?, Foundation for the Conservation of Modern Art/ Netherlands Institute for Cultural Heritage, Amsterdam (1999) 247-249.

4 Haiml, C., 'Restoring the immaterial: Study and treatment of Yves Kleiń s Blue Monochrome (IKB 42)', in Modern Paints Uncovered, ed. T. J. S. Learner, P. Smithen, J. W. Krueger and M. R. Schilling, The Getty Conservation Institute, Los Angeles (2007) 149-156.

5 Feller, R.; Kunz, N., 'The effect of pigment volume concentration on the lightness and darkness of porous paints', in AIC Preprints of the 9th Annual Meeting, American Institute for the Conservation of Historic and Artistic Works, Washington (1981) 66-74.

6 Hansen, E. F.; Walston, S.; Bishop, M. H. (ed.), Matte Paint. Its history and Technology, Analysis, Properties and Conservation Treatment, Getty Conservation Institute, Los Angeles (1994).

7 Hansen, E.F.; Lowinger, R.; Sadoff, E., 'Consolidation of porous paint in a vapor-saturated atmosphere: a technique for minimizing changes in the appearance of powdering, matte paint', Journal of the American Institute for Conservation 32(1) (1993) 1-14, doi:10.1179/019713693806066519.

8 Michalski, S.; Dignard, C., 'Ultrasonic misting. Part 1, experiments on appearance change and improvement in bonding', Journal of the American Institute for Conservation 36(2) (1997) 109 -126, doi:10.1179/019713697806373208.

9 Michalski, S.; Dignard, C.; Van Handel, L.; Arnold, D., 'The ultrasonic mister. Applications in the consolidation of powdery paint on wooden artifacts', in Painted Wood: History and Conservation, ed. V. Dorge and F. C. Howlett, The Getty Conservation Institute, Los Angeles (1998) 498513.

10 Pataki, A., 'Einflussgrößen auf den Farbeindruck von Pudernden Malschichten beim Konsolidieren mit Aerosolen', dissertation, Staatlichen Akademie der Bildenden Künste Stuttgart, Stuttgart (2005).

11 Horton-James, D.; Walston, S.; Zounis, S., 'Evaluation of the stability, appearance and performance of resins for the adhesion of flaking paint on ethnographic objects', Studies in Conservation 36(4) (1991) 203-221, doi:10.1179/ sic.1991.36.4.203.

12 Swider, J. S.; Smith. M., 'Funori: overview of a 300-year-old consolidant', Journal of the American Institute for Conservation 44(2) (2005) 117-126, doi:10.1179/019713605806082329.

13 Llamas, R.; Reina, A., 'Study on the application of three adhesives used in the consolidation of contemporary paintings', Conservar Património 13 (2011) 27-36. 
14 Llamas, R.; Reina, A., 'The combined use of the ultrasonic atomizer with low-pressure micro table in the consolidation of contemporary paintings', in Proceedings of the Adhesives and Consolidants for Conservation Symposium, Canadian Conservation Institute, Ottawa (2011) 106.

15 Geiger, T.; Michel, F., 'Studies on the polysaccharide Junfunori used to consolidate matt paint', Studies in Conservation 50(3) (2005) 193-204, doi:10.1179/ sic.2005.50.3.193.

16 Melgosa, M.; Pérez, M.; Yebra, A.; Huertas, R.; Hita, E., 'Algunas reflexiones y recientes recomendaciones internacionales sobre evaluación de diferencias de color', Óptica Pura y Aplicada 34 (2001) 1-10.
Received:: 13 March 2014

Revised: 21 January 2015

Accepted: 22 January 2015

Online: 27 February 2015

This work is licensed under the Creative Commons Attribution-NonCommercial-NoDerivs 3.0 Unported License. To view a copy of this license, visit http://creativecommons.org/licenses/by-nc-nd/3.0/deed.pt. 